\title{
CLIMATE CHANGE EFFECTS ON SKI TOURISM
}

\author{
Piroska Béki ${ }^{1}$ \\ ${ }^{1}$ Marketing and Tourism Institute, Tourism and Catering Department, \\ University of Miskolc. Egyetemváros, Miskolc 3515 \\ piroska.beki@gmail.com
}

\begin{abstract}
Nowadays, climate change poses a common recurring problem in our everyday life. The weather forecasts tend to be inaccurate, the swiftly changing weather often makes fun of the people. The same unpredictability applies for forecasting the amount of precipitation or snowing. The major problem in ski tourism consists in the gradual shift of seasons, namely there is no snow in December yet, while at Easter-time we can count on such an enormous amount of snow. I'd like to present this climate condition and offer a sort of way out of this problem.

In my empirical study, I have carried out document-analysis along the data collection phase, and I made half-structured deep-interviews, as well. My research questions were the following: How is the winter season affected by climate change or by the lack of snow? Due to the unreliable climatic conditions what is the estimated ratio of drop in tourism in the season? How much shorter is a skiing-season and how does it affect the operation of the local ski-school? What are the features of pre, and post peak-season tourists' emergence? How and for how long can a smaller ski-resort be maintained? What is the biggest challenge, problem at the ski-resorts along the state border?

First of all, I'd like to present and tackle the various solutions emerged facing the challenges of climate change effects related to skiing, on the other hand, I have made some personal interviews with Hungarian ski instructors working abroad and also with managers of Austrian ski schools trying to find out the various answers and reactions they have hammered out coping with the new challenges and difficulties in ski tourism.

Hungary can not be considered a skiing nation, although more and more people tend to take up skiing and get involved in this special field of sport tourism. The number of ski slopes being built and developed is increasing, yet the Hungarians ski-lovers tend to visit rather the foreign sport centers for the time being. The reasons mostly involve the various length and versatile difficulty level of the ski slopes. We should also take into account the challenging conditions imposed by climate change on the smaller winter sport centers and the way they can cope with it and also compete with other sport centers with similar features.

Climate change affects considerably the operation of skiing season, and the service providers must adapt to the new conditions. Many resort venues struggle for survival, though most of the local self-governments are clearly aware of the importance of ski-tourism, particularly in Austria.
\end{abstract}

Keywords: climate change, ski tourism, winter sport centers

(JEL Code: Z32)

\section{INTRODUCTION}

Tourism proves to be a global issue. At the beginning of the 21st century, in the developed regions of the world leisure-time spending has become organic part of everydaylife, thus it has constantly played an important rejuvenating factor in economy. Obviously, tourism is not independent from the socio-economic transformations, either. Sport and tourism are supposed to be two 'mega-fields' of our society involving millions of people. Both areas significantly affect the social, cultural and economic lives of countries as well as their foreign relations. Their ensuing merger resulted in the emergence of sport-tourism and its rapid dynamic development, too (RÖTHIG, 1992; DREYER, 2002; BÁNHIDI, 2007, BORBÉLY and MÜLLER 2008, MÜLLER et al. 2008).

The nuisance effects of climate-change upon tourism and catering have gained more ground and awareness along the last decade. Moreover, due to the negative trends in climate change several intensive development projects have been implemented for creating and providing snow-sure resorts in winter tourism.

Ski-tourism emerged only a few decades ago as a new kind of service and primary motivational objective in masstourism. It has spread primarily across the West-European countries. At the early stage it used to be the active leisuretime touristic activity of the elite, while the number of winterholiday makers started to increase with launching of the second and even third holidays among workers. The various skiing package-tour offers of the travel agencies generally provide similar complex touristic services used and paid for by great bulk of common customers.

The soaring popularity and development of winter tourism stems from the advanced by-services of the ski-slopes and resorts, the slopes have become snow-sure (thanks to the effective application of snow-cannons) and they also provide higher level facilities for the lovers of winter-sports. Thus, an increasing number of tourists tend to choose the domestic skiresorts, as well, which are more cost-effective and affordable 
than the facilities provided by the resorts of the neighbouring countries. According to the surveys - in our country - around $5 \%$ of the population gets actively involved in ski-tourism, each year (sielok.hu). The ski-lovers' primary choice is still Austria, where Hungary stands consistently on the 10th position among the international group of outstanding skitourists-sender countries. For instance, a record number of Hungarian winter tourists arrived in Austria in 2013. Based upon the figures of Statistik Austria, 479,083 Hungarian tourists spent altogether 1,622,437 guest-nights in Austria. The biggest number of Hungarian tourists visited Stayermark, Salzburg province, Carinthia and Vienna (Österreich Werbung Budapest).

In my study, from one hand, I wish to present the opportunities and problems facing the smaller ski-resorts along our state-border, the way people react to the challenges posed by climate-change; from the other hand, I tend to unveil the findings of my interview-based survey conducted among Hungarian ski-instructors working abroad and managers of Austrian ski-schools, too, concerning their alternative proposals on the new unfolding challenges and problems.

\section{MATERIALS AND METHODS}

\section{Tourism and climate-change}

Tourism, based upon its diversity can be listed and structured in many different ways. Among its categories there are quite many overlappings, thus the clear ramification is pretty difficult. At the 1989 World Tourism Organisation (WTO) conference held in The Hague, regarding its primary motivation tourism was split into two major categories: professional and leisure-time tourism (MICHALKÓ, 2004). This is quite an important issue to be emphasized, since professional tourism, which proves to be one of the most developing areas of tourism, had not been dealt with separately before the conference.

Nowadays, many consider tourism as being the most characteristic industrial field and product of our modern age. Tourism proves to be a complex social issue, where the environment holds an important role. Tourism must be regarded closely together with its environment in all cases. There is a tight interaction and mutual dependence between tourism and environment, since some factors of environment do affect tourism while the latter has its own reaction and impact upon the environment, though the scale of the two impacts cannot be considered equal and balanced.

Leiper (1981) considered to carry out the research of tourism in multi, - and interdisciplinary way. In his model, the key dimensions of tourism are to be: the tourists, the sender areas, travelling, destinations and the tourism-field (Fig. 1). In our days, the research of tourism is featured by the application of vast scale of theoretical approaches and methods. A common platform of all the various theories, approaches, ideas and models could greatly benefit and promote the dissemination of scientific know-how in tourism (PÉTER, 2010).
Figure 1.: The system of tourism extended

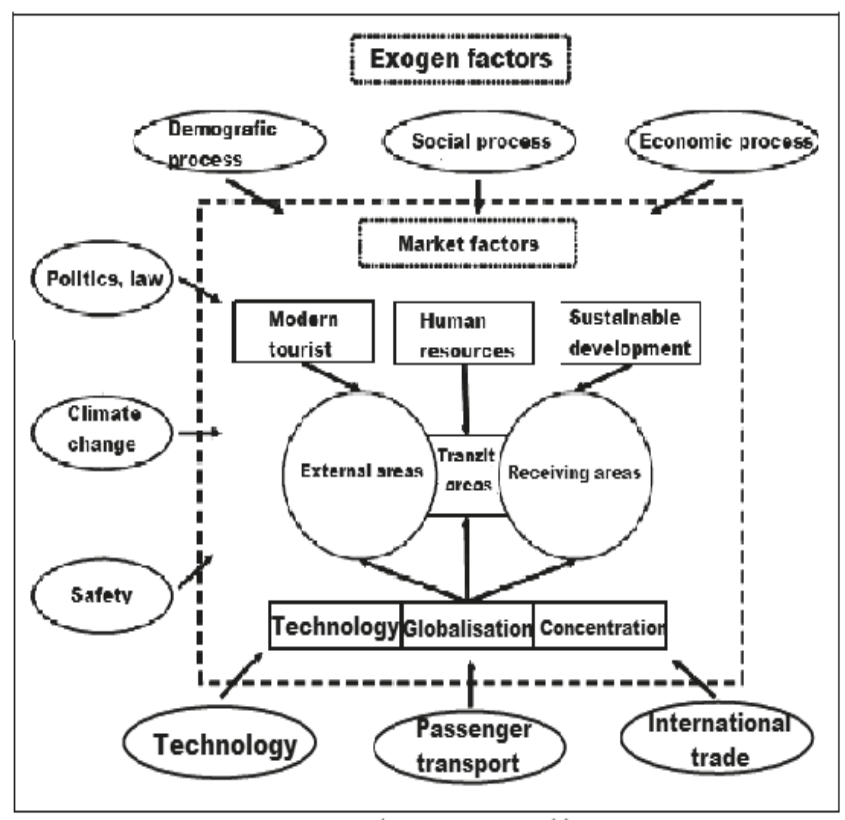

(LEIPER, 1981:75)

Generally, climate researchers provide weather-related figures linked to climate change, which do correlate with tourism. Factors, like sense of heat and stress (temperature indices), physical criteria (wind, rain, snow, ice and UVradiation, extremities, etc.) and aesthetic factors (such as, visibility, sunny periods, cloudiness, day-length etc.) (DE FREITAS, 2003; MATZARAKIS, 2006). Climate and weather conditions prove to be important factors of tourists' adventures and experiences of well-being, which interfere with the various weather-types and tourism relying upon threshold indices (GATES, 1975; BARBIERE, 1981; BESANCENOT, 1989, MÜLLER et al. 2011, MÜLLER et al. 2016). Earth's global surface temperatures in 2017 ranked as the second warmest since 1880, according to an analysis by NASA (2017).

There have been several studies carried out on the effects of climate change upon tourism, though quite often the researches tended to focus primarily on certain aspects of tourism, only (OECD, 2007; UNWTO-UNEP-WMO, 2008; SCOTT, 2011). It has been revealed that the impact and effect of changing weather conditions upon tourism are quite diverse and versatile (MATZARAKIS et al. 2004; 2007; AMELUNG et al. 2007; SCOTT, 2006; SCOTT and MCBOYLE 2007), taken into account the correlation between weather/climate, climate change and tourism too (MATZARAKIS, 2006; 2010). In this study, the focus tends to be cast on winter tourism, particularly concentrating on the problem-sphere defined by the lack of precipitation and snow.

\section{From sport-tourism to ski-tourism}

Sport, as one form and way of spending time outdoors in nature, proves to play an indispensable role in promoting and facilitating environmentally conscious lifestyle and attitude... 
Quite many studies deal with the supply and demand, economic factors of sport-tourism and also with the motivation of target groups (BÁNHIDI, 2007; BÁNHIDI et al. 2006; BORBÉLY and MÜLLER 2015, DOBAY, 2008; MÜLLER et al 2007, PREUSS, 2004, MÜLLER et al. 2006, MOSONYI et al 2013). Sport and tourism, two major industrial fields have experienced significant development and rise in the recent decades (DÓCZI, 2008). The autonomous independencetrend of sport-tourism within tourism proves to be the result of intensive classification process (FÖLDESINÉ, 2005). The terminology in itself refers to such travel forms that primarily imply sport-related objectives and motives: to do sports, to take part in competitions, to support teams, fan-group travels and to visit sport sights and facilities. Furthermore, based on the various sport-fields, sport-tourism can be split into as many fields as the number of sport-related activities exists, such as: biking, skiing, horse-riding, water-sports etc (BÉKI, 2015, KÖNYVES and MÜLLER 2001).

Consequently, the term of sport-tourism tends to function as a cluster-term involving all kinds of sport-related activities, which can also be broken down into indoors and outdoors activities. The outdoor-activities evidently are exposed to the climatic conditions. It is commonly known, that the sport facilities on higher altitudes are more affected by the warmer climate - especially - the winter sport conditions and all the linked sport activities (SCOTT et al. 2003, 2006; 2011). According to the surveys made by Matzarakis and Tinz (2008), the climate change conditions and its consequences in the alpine regions will be the following:

a. changes in some aspects of climate-tourism,

b. risks and dangers posed by climatic and other natural disasters,

c. changes in snow-conditions,

d. changes in bio-diversity (HALL, 2010).

The skiing-season might as well be shortened in the middle-altitude mountain regions, thus the winter-sport facilities would be available only at the higher altitude resorts of these mountains. In the Alps, the snow-sure slopes and resorts would start at $1,500 \mathrm{~m}$ altitude and by the end of the 21 st century the snow-coverage would also shrink with $50 \%$ (OECD, 2007). With each $1^{\circ} \mathrm{C}$ rise in average temperature the snow-border would climb 150 meters higher in the mountains, and, as a result the snow-coverage would decrease, respectively (ENDLER and MATZARAKIS 2011).

An area can expect financial gains in case it can assure and provide snowy skiing facilities for the winter-tourists, namely to be snow-sure. The most common method for defining 'snow-sureness' proves to be the 100-day rule. Namely, if a terrain is available for skiing for a time period of at least 7 seasons out of ten, for at least 100 days between 1 December and 15 April, and the snow-depth is at least of 30$50 \mathrm{~cm}$, then it can be considered to be snow-sure (ENDLER and MATZARAKIS 2011). This method is applied by the OECD-study (2007), as well, and the findings reveal that a temperature rise of $2^{\circ} \mathrm{C}$ in Europe would result in significant drop of snow-cover in the Alps; only $60 \%$ of present skiresorts would remain snow-sure. During the outstandingly warm winter of 2006 many ski-resorts could not continuously operate from December to April, with the exception of slopes where snow-cannons were used, too (WOLFSEGGER et al. 2008; STEIGER and MAYER 2008; STEIGER, 2010; 2011).

It is an expected trend in the future to face the shrinking of skiing days as well as the increasing amount of artificial snow-making facilities. In some particular cases the various effects may be beneficiary as well, in case they combine the opportunities in the pre and post-peak-season, for example they may link the diverse touristic activities together (SERQUET and REBETEZ 2011).

\section{METHODS AND THE SAMPLE}

In my empirical study, I have carried out documentanalysis along the data collection phase, and I made halfstructured deep-interviews, as well. I analysed the sielok.hu database, the KSH database and the Austrian OWB database documents.The subject of my deep-interviews were meant to be experts of winter-sports, who run ski-businesses or operate ski-facilities $(n=6)$, furthermore I questioned skiinstructors $(n=20)$ who are involved in skiing during the whole winter season. The pre-arranged list of questions was posed personally or via Skype meetings.

My research questions were the following:

How is the winter season affected by climate change or by the lack of snow?

Due to the unreliable climatic conditions what is the estimated ratio of drop in tourism in the season?

How much shorter is a skiing-season and how does it affect the operation of the local ski-school?

What are the features of pre, and post peak-season tourists' emergence?

How and for how long can a smaller ski-resort be maintained?

What is the biggest challenge, problem at the ski-resorts along the state border?

\section{RESULTS AND DISCUSSION}

The condition of ski-slopes based upon the research study

The interviews shared various approaches when trying to find appropriate answers for the questions concerned. Without precipitation and missing cold weather the ski resorts cannot start their winter operations. During the winter months, particularly in December, the travel agencies cannot assure their tourist customers whether they would be able to ski or not at the chosen ski resorts. Thus, a new term popped up in tourism industry, namely the snow-guarantee. This idea instigates and facilitates customers to invest into winter-travels to ski-resorts even in December, in the worst case they would get a refund. The peak-season periods are usually exempt from this service. The last 5 years' experiences manifest that mostly the glaciers are able to provide appropriate number and quality of ski-slopes in December period, from which the current season seems fortunately enough to be an exception. 
All my interviewees, without exception, reassured me that the ski-resorts badly needed cold weather in the current season. The water-stock reserves and the ensuing cold weather can provide the necessary good level ski-slope conditions with the application of snow-cannons. The winter season usually lasts for 3.5-4 months from mid-December until end of March or mid-April. The experiences of the previous 5 years, though let us consider that the heavy snow-falls usually occur at the beginning of April, all the same the majority of the ski-tourist finish their winter holidays by the end of March. April is not commonly considered a month for skiing, thus the ski-resorts with good snow quality and depth are forced to close their doors, though with some progressive shift and change in mentality and the season could be prolonged with a one month later start and finish winter holiday re-scheduling. This shift naturally needs time since the idea of white Christmas and similar climatic concepts prevail in mentality.

The changing climatic and weather conditions pose serious problems for the tour-guides as well as for the ski-instructors. From one hand, if there is not enough snow that is a problem, from the other hand if it is too much that is another issue, too. In other words, it means that if there is too much and deep snow it may cause avalanche disaster, therefore it must be diminished with targeted explosions so the slopes must be closed, too. Many ski-slope accommodations are basically inaccessible, especially in case they can be reached only by cable-car. The summit lodges constitute outstanding marketing power and are attractive among winter-tourists just because their sheer venue, though in case of big snowfall or avalanches they can become stranded or cut off from civilization for several days. Strong winds are meant to pose another hazard factor in the mountains, which may lead to closing of the slopes and ski-lifts. For the time being, there are no solutions for these issues which are furthermore aggravated by the inaccurate weather forecast reports. The third problem stemming from climate change proves to be the sc. inverse effect, which assumes the phenomenon that in the populated valleys it is often much colder than up on the mountains. It can occur even stunning temperature difference of 10 degrees, which results in heavy snow-fall in the lower valleys and rain in the mountains. The hot winds then the rain make big changes in the snow conditions in the mountains, even ruining the built-up basements of the resorts. Not to mention the dangers posed by the rapidly changing temperature scales, too.

Since the snowy period of the winter holiday has shortened furthermore many countries have launched the system of winter school-breaks it all contribute to jammed and overcrowded resorts and slopes in a peak season. This effect also involves the conditions of the resorts and accommodations, which are mostly empty in December while are overbooked in January-February. Many bigger slopes try to expand and develop their lodges and services, which result in the creation of small ski-resort villages along the slopes as part of their marketing survival strategy. The interviewees claimed that they have experienced no decline in the number of winter tourists; however the skiers tend to accumulate.
This may cause serious problems when the capacities of the available ski-slopes diminish due to the lack of snow and cold weather. It also results in extremely dangerous and risky cases of having only a few available slopes overflowed by skiers. Furthermore, the deterioration of slopes also accelerates, which may cause bumpy and icy slopes for the afternoon hours, other danger factors for the skiers.

The local ski-school try to adapt to the new circumstances by hiring less full-time ski-instructors, in the peak-season - January, February - they tend to employ ski-instructors with definite short-term contracts. Unfortunately, this causes, quality deterioration, as the manager of Amigos ski-school from Mariazell asserted, since the schools cannot easily and quickly find skilful, experienced instructors for a short term, therefore they are forced to hire even instructors they would not employ at all in normal situations. Another option for the ski-schools is to obtain multi-functional employees, who can work in the schools as well as in the lodges, hütte or in case the school possesses accommodation, they can deal with those services, too. This is quite rare, though. Nowadays, ski-schools tend to employ instructors who can cope with instructing any kind of winter sports not exclusively skiing.

In the pre-season period, namely in December, one can witness the lack of tourists; their number has been plummeting due to the unpredictable and unreliable snow-conditions. The ski-lovers rather undertake the risks of using overcrowded slopes with queues of skiers in peak-season, when the snowsure resorts operate with full gear. The hotels and travel agencies are keen on filling up these low-profile gap-periods with all kind of side-services and programmes, such as skitests, or venues of ski-world cups, even though they cannot compete with the snow-sure bookings of the peak-season period.

Two years ago, for instance in the late season of Kreischberg due to the late heavy snow-fall in April the ski lift operator company made a decision to prolong the operational period with a week. Despite the perfect snow-conditions there were only very few skiers on the slopes who could heartfully enjoy the unforgettable great conditions. The company accounted for financial loss that week so this elongated operation idea was cancelled.

The lower altitude slopes can benefit from their special micro-climatic conditions preserving cold weather and snowcover. The slopes facing North and safe from extreme weather conditions prove to be much more snow-sure. Praebichl is located on lower altitude, yet surrounded by mountain passes, thus it possesses a special cold micro-climate with cold air-masses stuck in the valley. This fact, from one hand contributes to better slopes and snow-conditions, on the other hand, it has usually 5 degrees colder temperatures than the neighbouring settlements. There are no high mountains in Lower-Austria, though its skislopes and resorts enjoy great popularity among winter tourists, typically for one-day trippers. The largest Austrian province used to have more than 60 ski-slopes, this number has fallen to almost half by the present days. On the ruthless field of market-economy the crisis started with the bankruptcy of the mono-ski-lift slopes and the process developed further on. 
Then, by the first half of the 2000's years the bigger slopes went bankrupt as well, first - the snow-sure - HohenbergGschwendt, near Aegyd declared bankruptcy, and since then the ski-trekkers gained ground on the abandoned slopes until nature takes them over, definitely. Maria SchutzSonnwendstein followed track a few years later, when the ski-resort near Semmeringen lacked the necessary funds for development, despite several projects, business plans e.g. to connect it with Hirschenkogel. The plans evaporated quickly and Sonnwendstein got locked down.

Türnitz came to join the club soon as well, facing serious financial problems; consequently both Lower-Austrian skiresorts last only in our memories. In the summer of 2012 even Höchkar, the border-area snow-paradise came into dangerous spotlight: who might have imagined that the most snow-sure ski-resort of the province struggles with serious problems. Finally, thanks to the cooperation of the locals, it has survived the crisis, unlike St.Corona, lying among the hills of Wechsel, which was forced to close down after the skiing season of 2012, causing real headache for the lodge and shelter-providers of the area. Joining St.Corona also Königsberg closed down, soon.

The Austrian Hebalm reporting economic financial problems went bankrupt 2 years ago. This ski-resort was considered to be among the smaller ones in Austria. Interestingly enough, they referred to the 2009 global financial crisis as primary reason for closing down. Back then they realised that the slope-lodges were short of capacities around the ski-slopes. They also interpreted this problem as a consequence of the mentality-shift of the skiing customers who tended to prefer the bigger resorts also choosing versatile services after the crisis. Tourists choosing the smaller slopes also expect it to be close by not travel too much for it. Maintaining and developing the resorts and slopes demand investors in order to be competitive with the bigger ones.

Mariazell have also struggled for survival in the recent years, luckily the colder weather arrived and the waterreservoirs proved to be sufficient for snow-cannoning the slopes.

Two Swiss ski-resorts, first from among the European ski-resorts, reacting to the new conditions have undertaken the idea of offering lower-priced ski passes in case of bad weather conditions. On cloudy, snowy days they offer halfprice ski passes and tickets. The two ski-resorts of two Swiss cantons have made cooperation agreement with the University of St.Gallen and the meteorological institute so as to provide weather-related passes for their skiing customers. The worse might the predictable weather be, the cheaper they offer their ski-passes. Provided the weather forecast includes the 'partly sunny spots or partly snowy' phrases, the ski-passes can get $18 \%$ cheaper. It seems that the 'cloudy, but snowy' weather forecast is considered to be even worse since the passes drop with $28 \%$. And the worst weather scenario proves to be the 'cloudy but strong snow-fall' prediction when the prices drop $50 \%$ for the daring skiers.

\section{ACKNOWLEDGEMENT}

Climate change affects considerably the operation of skiing season, and the service providers must adapt to the new conditions. Many resort venues struggle for survival, though most of the local self-governments are clearly aware of the importance of ski-tourism, particularly in Austria. The local ski-schools provide more and more opportunities and the local service-providers tend to accommodate and adapt to the needs of the Hungarian customers. The present trend relies on the idea of 'the bigger the slope, the cheaper is skiing'. If we have paid for something, than we should get the utmost benefits from it. However, pushing the prices down also implies quality-deterioration. Increasing number of Austrian lodges and hotels are taken over by Hungarian operators, who cannot provide the common high-quality services for the lower prices. Many venues display the 'we can also speak Hungarian' inscription which may result in serious business advantages.

The problem behind the closing down of the neighbouring ski-resorts proves to be quite complex with multiple contributing factors. From one hand, there is the ensuing customer-drop after the 2008 global financial crisis, than on the other hand the effects of the much warmer and drier winters experienced along the recent years. While in the Western Austrian provinces there was a record-amount of snow last year, in Lowe-Austria the big snow-fall arrived much later. The weather fronts coming from the West tend to be weaker and numberless ski-resorts and slopes are located on lower altitudes at around 1,000 ms or so, or even lower.

Thirdly, the biggest problem for the border-area ski-resorts lies in their one-day ski-centre status. As such, they can generate much lower income, not to mention their significant exposure to the changing weather and snow-conditions, since in case of bad weather or poor snow much less winter-tourists tend to arrive. From among the winter resorts in the province, primarily and almost exclusively the Semmering-valley resorts are free of this kind of problems, though this is valid especially for Stuhleck resort, which belongs to Stayermark.

Not even the glaciers can operate all year round for 365 days, what's more, snow-cannons have also appeared at 3,000 $\mathrm{m}$ altitude for the last 10 years. This process seems to be unstoppable, since the glaciers are continuously melting and the snow-border is being pushed higher. At Pitztalon there is a snow-making machine in operation which can produce snow on a given temperature on the spot and they just simply spread it on the slopes.

Experts say that the Alpine ski resorts are facing the loss of up to $70 \%$ of their snow cover by the end of the century and this is a real tragedy. Last year the Swiss Alps had their driest December since records began 150 years ago. 2016 was the third year in a row with little snow at Christmas, when many families go for skiing.

The question remains that for how long in the future we would be able to enjoy the natural environment of the skislopes, whether this process is sustainable and where it would end up. 


\section{REFERENCES}

Amelung B, Blazejczyk K, Matzarakis A. (2007) (eds): Climate change and tourism: assessment and coping strategies. MaastrichtWarsaw-Freiburg, ISBN: 978-00-023716-4

Bánhidi M. (2007): Sporttudomány és turizmus. Magyar Sporttudományi Szemle 8. 30, 2007/2, 32-38.

Bánhidi M. Dobay B. Starhon, GK., Edvy, L. (2006): Kutatási programok a földrajzi környezet és sport összefüggéseinek megismeréséhez. Napjaink környezeti problémái - globálistól lokálisig Pannon Egyetem, Georgikon Kar, Keszthely.

Barbiere EB. (1981): O Fator Climático nos Sistemas Territoriais de Recreação. Revista brasileira de geographia 1981. 18(2):145-265

Béki P. (2015): Rekreáció-menedzsment. A tananyag elkészítését a ,'3.misszió” Sport és tudomány a társadalomért Kelet-Magyarországon TÁMOP-4.1.2.E-15/1/Konv-2015-0001 számú projekt támogatta. A projekt az Európai Unió támogatásával, az Európai Szociális Alap társfinanszírozásával valósult meg. Campus kiadó, Debrecen. ISBN 978-963-9822-42-9

Besancenot JP. (1989): Climat et tourisme. Masson: Collection Géographie, Paris, 1989. ISBN 2225818169

Borbély A., Müller A. (2008): A testi-lelki harmónia összefüggései és módszertana. Valóság-Térkép-6. PEM tanulmányok (Kiadja: a Professzorok az Európai Magyarországért Egyesület, Bp. szerkeszti: dr. Koncz István)

Borbély A., Müller A. ( 2015): Sport és Turizmus. Campus Kiadó, Debrecen. ISBN 978-963-9822-36-8

de Freitas CR. (2003): Tourism climatology: evaluating environmental information for decision making and business planning in the recreation and tourism sector. Int J Biometeor 2003.48:45-54

Dobay B. (2008): Sportturizmus kutatásában alkalmazott módszerek. XXI. Didmattech Konferencia, 2008. okt. 29-30., Eszterházy Károly Fôiiskola, Eger,

Dóczi T. (2008): Sportturizmus Magyarországon a számok tükrében. Magyar Szociológiai Társaság konferenciája, Veszprém, 2008. november 14.

Dreyer A. (2002): Sport und turismus. Wirtschaftliche, Soziologische und Gesundheitliche Aspekte des Sport-Turismus. Universitatsverlag, Wiesbaden.

Endler C, Matzarakis A. (2011): Analysis of high resolution simulations for the Black Forest region from a point of view of tourism climatology - a comparison between two regional climate models (REMO and CLM). Theor Appl Climatol 103:427-440

Földesiné, Sz Gy.(2005): Sportturizmus: új kihívások és stratégiák. Kalokagathia, 18 (1-2). 92-114.

Gates AD. (1975): Le climat des Maritimes en fonction du tourisme et des loisirs de plein air. Environment Canada, Toronto.

Hall CM. (2010): Tourism and biodiversity: more significant than climate change? J Herit Tour 5(4):253-266

Könyves E. Müller A. (2001): Szabadidős programok a falusi turizmusban. Könyv. Szaktudás Kiadó Ház, Budapest.

Leiper, N. (1981): Towards a Cohesive Curriculum in Tourism: The Case for a Distinct Discipline. Annals of Tourism Research, 1981:8, 69-83.

Matzarakis A (2006): Weather and climate related information for tourism. Tour Hosp Plan Dev 2006: 3:99-115

Matzarakis A.(2007): Assessment method for climate and tourism based on daily data. In: Matzarakis A, de Freitas CR, Scott D (eds) Developments in tourism climatology. Commission Climate, Tourism and Recreation, International Society of Biometeorology. 2007.

Matzarakis A. (2010): Climate change: temporal and spatial dimension of adaptation possibilities at regional and local scale. In: Schott C (ed) Tourism and the implications of climate change: issues and actions. Emerald Group Publishing. Bridging Tourism Theory and Practice, 2010 vol. 3, 237-259

Matzarakis A, de Freitas C, Scott D (2004) (eds): Advances in tourism climatology. Berichte des Meteorologischen Institutes der Universität Freiburg Nr. 12

Matzarakis A, de Freitas CR, Scott D (2007) (eds) Developments in tourism climatology. ISBN 978-3-00-024110-9

Matzarakis A, (2008): Tinz B. Tourismus an der Küste sowie in Mittel und Hochgebirge: Gewinner und Verlierer. In: Lozán JZ, Graßl H, Jendritzky G, Karbe L, Reise L (eds) Warnsignal Klima: Gesundheitsrisiken Gefahren für Menschen, Tiere und Pflanzen. GEO/ Wissenschaftliche Auswertungen, 2008. 247-252

Michalkó, G. (2004): A turizmuselmélet alapjai, Kodolányi János Főiskola, Székesfehérvár, 2004..

Müller A. Széles Kovács Gy. Seres J. Bocz Á. (2009): A sítáborok megítélése a Szegedi Tudományegyetem JGYTFK „sportszakos” hallgatói körében. In: Acta Academiae Pedagogicae Agriensis. XXXV. Kötet. 2009. 57-68.

Müller A. Széles Kovács Gy. Seres J. Bocz Á. (2007): A sporttáborok szerepe az Eszterházy Károly Főiskolán. In: Acta Academiae Pedagogicae Agriensis. XXXIV. Kötet. 2007. 105-117.

Müller A. Könyves E. Várhelyi T. Mondok A. (2008): Új utakon a testnevelô tanárképzés Egerben - A sportszakos hallgatók utazási szokásainak, és a sítáborozás kínálati elemeivel való elégedettségének vizsgálata. ECONOMICA. 2008.1. 85-95.

Müller A. Kerényi E. Könyves E. Effect of Climate Therapy and Rehabilitation in Mátra Medical Institute Applied Studies in Agribusiness and Commerce - APSTRACT.5. (3-4.) Debrecen, Agroinform Kiadó. 2011.40-42.

Mosonyi A. Könyves E. Fodor I. Müller A. Leisure activities and travel habits of College students int he light of a survey. Applied Studies in Agribusiness and Commerce - Apstract. Vol.7. iss.1. pp. 53-57. 2013.

Müller A. Barcsák B. Boda J. E. (2016): Health tourism the cavebath of Miskolctapolca. In: György Juhász, Enikő Korcsmáros, Erika Huszárik (szerk.) Korszerú szemlélet a tudományban és az oktatásban. Gazdaságtudományi szekció: Zborník medzinárodnej vedeckej konferencie Univerzity J. Selyeho - 2016 „Súcasné aspekty vedy a vzdelávania”. Sekcie ekonomických vied. 278 p. Konferencia helye, ideje: Komárno, Szlovákia, 2016.09.13-2016.09.14. Komárno: Selye János Egyetem, 2016. 233-245.

OECD (2007): Climate change in the European Alps-adapting winter tourism and natural hazards management. Hrsg. von S. Agrawala (eds) OECD, Paris.2007.

Péter, Zs. (2010): A turizmus térségi folyamatainak összefüggései, különös tekintettel az észak-magyarországi régióra, $\mathrm{PhD}$ értekezés, Miskolci Egyetem, GTK. 2010.

Preuss, H. (2004): The Economics of Staging the Olimpics. A comparison of the games. MPG Books LTD. Bodmin, Cornwall. 2004. 1972-2008.. ISBN: 1843768933

Röthig, P.(1992): Sportwissenschaftliches Lexikon. Hofmann, Schorndorf. 1992. 
Scott D. (2006): Global environmental change and mountain tourism. In: Gössling S, Hall CM (eds) Tourism and global environmental change. Routledge, London. 2006.

Scott D. Why sustainable tourism must address climate change. J Sustain Tour. 2011. 19(1):17.34

Scott D, Matthews L. (2011): Climate, tourism \& recreation: a bibliography-2010 edition. Department of Geography and Environmental Management, University of Waterloo, Waterloo. 2011.

Scott D, (2007): McBoyle G. Climate change adaptation in the ski industry. Mitig Adapt Strateg Glob Chang 2007. 12(8):1411-1431

Scott D, McBoyle G, Mills B. (2003): Climate change and the skiing industry in southern Ontario (Canada). Clim Res 2003. 23:171- 181

Scott D, McBoyle G, Minogue A, Mills B.(2006): Climate change and the sustainability of ski-based tourism in Eastern North America: a reassessment. J Leis Res 2006. 14:376-398

Serquet G, Rebetez M (2011): Climatic change, relationship between tourism demand in the Swiss alps and hot summer air temperatures associated with climate change. Clim Change 2011. 108:291-300. doi:10.1007/s10584-010-0012-6

Steiger R (2010): The impact of climate change on ski season length and snowmaking requirements in Tyrol, Austria. Clim Res 2010. 43:251-262

Steiger R (2011): The impact of snow scarcity on ski tourism. An analysis of the record warm season 2006/07 in Tyrol (Austria). Tourism Rev 2011. 66(3):4-13

Steiger R, Mayer M (2008): Snowmaking and climate change. Future options for snow production in Tyrolean ski resorts. Mt Res Dev. 2008. 28:292-298. doi:10.1659/mrd.0978

UNWTO-UNEP-WMO (2008): Climate change and tourism- responding to global challenges. UNWTO Madrid, Spain 2008.

Wolfsegger C, Gössling S, Scott D Climate change risk appraisal in the Austrian ski industry. Tour Rev Int 2008. 12:13-23

https://www.ncei.noaa.gov/news/global-climate-

201712? position $=0 \&$ list $=$ XPLk-qDkISLA2H-

PIP82IKLnmWd4TJU5qWILo8n9iFr4 (retrived: 01.01.2018) 
